\title{
Effect of feeding level on production performance of lactating Red Maradi goats and post-natal performance of kids
}

\author{
N. ABDOU ${ }^{1, *}$, A.S. GOURO ${ }^{2}$ and I.V. NSAHLAI ${ }^{3}$ \\ ${ }^{I}$ National Institute for Agricultural Research of Niger, PB 429 Niamey, Niger. \\ ${ }^{2}$ Faculty of Agronomy, Department of Animal Production, University Abdou Moumouni of Niamey, \\ BP: 10960, Niamey, Niger. \\ ${ }^{3}$ University of KwaZulu-Natal, School of Agricultural, Earth and Environmental Sciences, Department of \\ Animal and Poultry Science, Pietermaritzburg Campus, Private Bag X01, Scottsville, 3209, South Africa. \\ *Corresponding author; E-mail: nourouabdu@yahoo.fr
}

\section{ACKNOWLEDGEMENTS}

The authors acknowledge the funding provided by the West Africa Agricultural Productivity Programme (WAAPP/PPAAO) of Niger (grant number: 4877-NE). Partial funding for laboratory analysis was obtained from P029 UKZN research code.

\begin{abstract}
Forty pregnant Red Maradi goats were used in Caprine Centre of Maradi (Niger) for two subsequent lactations from day one to day 14 of lactation to evaluate the effect of feeding levels of dams on production performances of dams and post-natal performance of kids; to determine the effect of previous levels of feeding dam on production performances of kid and dam; and to determine the ME intakes of kid and dam and their requirements based on AFRC and NRC systems. One diet was formulated for two kiddings as follows: $38 \%$ of crushed and urea-treated of millet stover (CUTMS), 32\% of groundnut haulms (GH), 22\% of wheat bran (WB) and $8 \%$ of cottonseed cake (CSC). For the first kidding until the second kidding, four treatments were constituted, T1, T2, T3, and T4, and formed respectively by four feeding levels $842,934,1079$ and $1300 \mathrm{~g} / \mathrm{kg}$ DM corresponding to $200 \mathrm{~g}, 400 \mathrm{~g}, 600 \mathrm{~g}$ and $800 \mathrm{~g}$ of milk production, respectively. A randomized block design was applied on 40 does according to body weight, parity and birth type implying 10 does per treatment, and forty-nine born kids of which thirty-one singles and eighteen twins were fed colostrum and milk using feeding bottles. During the second kidding, dams were fed with T4. Dry matter (DM) intake and ME intake of dams increased linearly $(\mathrm{P}<0.001)$ with increasing level of feeding. Kids ME intake (kMEint) increased linearly $(\mathrm{P}<0.05)$ during the first lactation with increasing level of feeding while there was no variation $(\mathrm{P}>0.05)$ of kMEint at the second lactation. The previous level of feeding, age and birth type affected (at least $\mathrm{P}<0.05)$ the final body weight and body weight change of dams. The kMEint observed were similar to ME requirements of AFRC but lower than that of NRC. To overcome the ME requirements of kids and lactating does of Red Maradi goats, the requirements of NRC system should be used.
\end{abstract}

() 2017 International Formulae Group. All rights reserved.

Keywords: Feeding levels, kids, metabolizable energy, post-natal performance, Red Maradi goat.

\section{INTRODUCTION}

The Red Maradi (Sokoto) goat is widely represented in Southern Niger and is the most important dual purpose goat breed due to its prolificacy and milk production. According to the 2007 statistics, the goat 
population in Niger was about 11238 268, which constitutes about $36.2 \%$ of the livestock (RGAC-Niger, 2007). Breeding activities and diffusion of the Red goat began in 1945. This breed has been part of the traditional farming system and has been selected in Maradi since 1963 in Caprine Centre of Maradi based on its ability to produce meat and milk. Maradi area constitutes the predilected agro-ecological zone of this breed. Nowadays, by efforts of Government, NGOs and Development Projects, Red Maradi goats are widely distributed in Niger and West African countries. The major constraint limiting the productivity of Red Maradi goat is the nutritional management of dams with repercussion on milk production, live weight losses, low post-natal performances of kids (Pamo et al., 2007; Snyman, 2010; Ukanwoko et al., 2012; Petros et al., 2014), and slow growth rate of kids (Nnadi et al., 2007).

Djibrillou et al. (1998) reported a general body weight loss of red Maradi goats fed untreated or urea treated straws supplemented with or without concentrate and attributed this to a negative energy balance. Nnadi et al. (2007) and Snyman (2010) included low birth weight, slow growth rate and insufficient milk production as main causes of kid mortality. The growth performance of kids after kidding and survival rates are the most important factors of animal production but not much work has been done on Red Maradi goats raised under semi intensive system in Southern Niger. Also, very little is known about the metabolizable energy requirements of kids and dams of this breed in early lactation. The Objectives of this study were to (1) evaluate the effect of feeding levels on production performance of dams; (2) determine the effect of levels of feeding of dams on post-natal performance of kids; (3) determine the effect of previous levels of feeding of dams on production performances of dam and kid; (4) determine the ME intakes of kid and dam and their requirements based on $\mathrm{AFRC}$ and NRC systems.

\section{MATERIALS AND METHODS}

\section{Study site}

The study took place in the Caprine Centre (1850 ha and 893 animals in 2012) located East of Maradi. It is situated in the sahelo-sudanian zone of Niger with a mean annual rain fall of $350-600 \mathrm{~mm}$, latitude $13^{0} 30^{\prime} \mathrm{N}$, longitude $7^{0} 6^{\prime} \mathrm{E}$ and an altitude of $347 \mathrm{~m}$ above sea level. The climate is relatively dry with the rainy season occuring between June and September. The dry season begins around the $15^{\text {th }}$ October with dry and cold weather from November to February. The hot weather occurs from March to June. The mean min/max temperature is $22 / 36{ }^{\circ} \mathrm{C}$ with a peak in April-May $\left(>40{ }^{\circ} \mathrm{C}\right)$; heat decreases when rains begin. The relative humidity from October to June and July to September are < $20 \%$ and $>80 \%$, respectively. The natural vegetation is SaheloSudanian woodland dominated by various Acacia species, with sparse ground regenerating shrubs and perennial or annual grasses.

\section{Animals and housing}

Forty (40) pregnant does were transfered from the flock of Red Maradi goats breeding centre to the feed research unit towards the end of pregnancy (one to two weeks before kidding). These does weighing $23 \mathrm{~kg}$ live weight $(\mathrm{SD}=3.65)$ were used in this experiment. After kidding, does were treated against external and internal parasites with Ivermectin (1\%), Limoxin (antibiotic) and one week later, they were vaccinated against pasteurellosis (pastovac). The following variables were recorded on each doe at the beginning of the study: ear-tag number, weight, age, parity, date of kidding, litter size and kid sex. Kids were ear-tagged on the second day of life, separed from their dams at the evening of kidding for 14 days. Does were allocated to four (4) treatments, according to body weight, parity and litter size making a total of ten (10) animals per treatment. Does were allocated to individual pen $(2 \mathrm{~m} \times 1.5 \mathrm{~m})$ in the experimental feed unit with free access to a salt lick and potable 
drinking water. In this experiment coinciding to the dry season, kid survival rate was $100 \%$.

After weaning kids at 3 months age, does continued on the same diet and oestrus was synchronized to reproduce dams, where 24 over 38 does conceived giving average conception rate of $63 \%$ of which $\mathrm{T} 1$ and $\mathrm{T} 2$ had the lowest (48\%) and T3 and T4 the highest (78\%) respectively. A similar experiment which was conducted in the rainy season to determine the effect of previous levels of feeding on the growth performance of kids and milk yield of does; where one treatment (T4) which gave the best milk production response at the previous kidding was applied to all the does.

\section{Feeds}

Feeds were chosen based on nutritive value and availability in the study area, and were constituted of crushed millet stover with urea-treatment $(38 \%)$, groundnut haulms (32\%), cottonseed cake (8\%), wheat bran (22\%) and mineral lick.

\section{Millet stover and groundnut haulms}

Millet stover was purchased $(0.25$ USD/5 kg bundle) from smallholder farmers immediately after harvesting when feed was available and cheap. Groundnut haulms were purchased from smallholder farmers, packaged in $15 \mathrm{~kg}$ bags each costing 2.58-5.16 USD (depending on the dry season or period of feed scarcity). Millet stover and groundnut haulms were crushed through a $10 \mathrm{~mm}$ sieve (Made Peruzzo, with electric motor single phase $3 \mathrm{HP}$ - 220 Volts - $2.2 \mathrm{Kw}, 5-10$ Holes mm, model A/5-R/75, Production: 100/500 $\mathrm{kg} /$ hour, $\quad \mathrm{http}: / / \mathrm{www}$.peruzzo.it/eng/66hammer-mill-a-5-r-75.html). Millet stover was treated with urea. Urea treatment was done by dissolving $4 \mathrm{~kg}$ of urea in 60 liters of water; and the solution was sprinkled onto $100 \mathrm{~kg}$ of millet stover, mixed properly, and then stored in polyethylene bags for 40 days in the barn. At the end of treatment, strong smell of ammonia, change in physical characteristics such as brown colour, heat and absence of moulds were observed.

\section{Wheat bran, cottonseed cake, mineral lick and urea}

These ingredients are available at the local Maradi market and from the regional livestock service at subsidised prices where wheat bran and cotton seedcake would cost $8.60 \mathrm{USD} / 50 \mathrm{~kg}$ bag. Mineral salt block (costing $0.68 \mathrm{USD} /$ stone of 2-2.5 kg) and urea (costing 17.21 USD/50 kg bag) were purchased from local dealers. Cottonseed cake was crushed through a $10 \mathrm{~mm}$ sieve with the same crushing machine cited above.

\section{Feeding management}

Before entering this experiment, goats were fed on natural grazing based on herbaceous forages dominated by Schizachyrium exile, Eragrostis tremulu, Diheteropogon hagerupii, and shrubs dominated by Guiera senegalensis, Bauhinia rufescens, and woody plants principally Acacia nilotica, Acacia radianna, Acacia albida, Piliostigma reticulatum and Balanites aegyptiaca. Feed troughs were made by cutting a barrel in three parts thus 3 feed troughs were made per barrel and pregnant does were transferred to the experimental feed unit. Then an adaptation period of about 14 days was observed, depending on the pregnancy period in order to familiarise animals to the diet comprising of urea treated millet stover (MS), groundnut haulms $(\mathrm{GH})$, cottonseed cake (CSC) and wheat bran (WB).

During adaptation, does were fed T2 which was supposed to meet the requirement for producing $400 \mathrm{~g}$ of milk in red Maradi goats known as optimum milk yield of this breed. Feed offered was measured with an electronic balance (Sartorius M-Power Toploader Balance, $6100 \times 0.1 \mathrm{~g}$ ) into plastic bags the previous afternoon just to avoid any delay in feeding the following day. Feed was offered in the morning at 8 o'clock and refusals were collected the following day between 7 and 8 o'clock am. Mineral lick was hung in individual pen permanently per animal as supplementary ingredient. Water was offered ad libitum. 


\section{The experimental design}

Forty animals were blocked according to weight, parity, litter size, and age, and distributed into four of 10 animals each, which were randomly allocated to four (4) treatments (T1 to T4), making a total of ten (10) does per treatment. Does were allocated to individual pens in the shed during the experimentation. Four groups (10 lactating does/group) received four feeding levels based on one diet from kidding until 14 days post kidding. The diet given in Table 1 was formulated following the AFRC (1993) recommendation and rationed to achieve various milk production targets.

T1: $842 \mathrm{~g} \mathrm{DM}$ of $\mathrm{D}_{1}$ for $200 \mathrm{~g}$ of milk production

T2: $934 \mathrm{~g} \mathrm{DM}$ of $\mathrm{D}_{1}$ for $400 \mathrm{~g}$ of milk production

T3: $1079 \mathrm{~g}$ DM of $\mathrm{D}_{1}$ for $600 \mathrm{~g}$ of milk production production

T4: $1300 \mathrm{~g} \mathrm{DM}$ of $\mathrm{D}_{1}$ for $800 \mathrm{~g}$ of milk

Treatments one to four were rationed to examine the effect of level of feeding. During the second experiment (lactation), one group of twenty-two (22) lactating does received one treatment (T4) from kidding to 14 days post kidding to determine the effect of previous treatments on milk production and post-natal growth performance of kids.

\section{Metabolisable energy intake and requirements of dams and kids according to AFRC and NRC systems}

The metabolizable energy (ME) intake of dams was derived from proportion of ME in feed intake and ME intake of kids was calculated from ME in colostrum and milk intake (Akinsoyinu et al., 1981). The ME intake of dams was calculated based on ME content of different ingredients. The ME was derived from effective degradability of organic matter of the same feeds (Abdou et al., 2017) based on suggestion by Nsahlai and Apaloo (2007) where $\mathrm{ME}=\mathrm{ED}_{\mathrm{OM}} * 15.06 / 0.9$, where 15.06 is a factor suggested by Czerkawski (1986).
The ME intake of kids was calculated as the sum of ME in colostrum plus milk (Akinsoyinu et al., 1981) for Red Sokoto (Maradi) goats. It was assumed after considering losses of energy in digestion, absorption and transportation, that seventy per cent $(70 \%)$ of milk GE was transformed into ME. The colostral phase was determined for each doe in order to calculate ME intake derived from colostrum phase.

Metabolizable energy intake of kid $($ MEint $)=$ SMEC + SMEM

Where: SMEC is the sum of ME derived from the quantity of colostrum intake and SMEM is the sum of ME derived from milk intake during the first 14 days of the study. The ME requirement (MEr) was calculated according to the AFRC (1993) and NRC (2007) systems as follows:

MEmr $($ AFRC $)=\mathrm{MEm}+\mathrm{NEg} / \mathrm{k}_{\mathrm{g}}$

Where $\mathrm{MEmr}=$ metabolizable energy requirement; MEm (metabolizable energy for maintenance $)=0.315 * \mathrm{Kwt}^{0.75} / \mathrm{k}_{\mathrm{m}}$; where $\mathrm{k}_{\mathrm{g}}$ and $\mathrm{k}_{\mathrm{m}}$ are efficiencies with which ME is used for production and maintenance respectively.

$\operatorname{MEg}(\mathrm{NEg}$, Net energy for gain $)=$ $\mathrm{EVg} * \mathrm{ADG} / \mathrm{k}_{\mathrm{g}}$

Where: EVg (energy value for gain) $=4.972$ $+0.3274 * \mathrm{Kwt}$; and $\mathrm{ADG}=$ average daily gain; $\mathrm{Kwt}=$ kid weight; $\mathrm{k}_{\mathrm{g}}$ is efficiency of use of $\mathrm{ME}$ for gain.

$\operatorname{MEmr}(\mathrm{NRC})=0.521 * \mathrm{Kwt}^{0.75}+13.4 * \mathrm{ADG}$

(for suckling male kids) and

$\operatorname{MEmr}(\mathrm{NRC})=0.449 * \mathrm{Kwt}^{0.75}+13.4 * \mathrm{ADG}$

(for suckling female kids)

The ME intake of dams was calculated based on ME content of diets (Table 1) as follows:

$\mathrm{dMEI}=(\mathrm{DI} / 1000) * \mathrm{MED}$;

$\operatorname{dMEr}($ AFRC $)=0.315 * \mathrm{dwt}^{0.75}-20 * \mathrm{dADG}+$ MEmk;

$\mathrm{dMEr}(\mathrm{NRC})=0.462 * \mathrm{dwt}^{0.75}-28.5 * \mathrm{dADG}+$ MEmk;

Where dMEI = dam metabolizable energy intake per day; DI = dam intake; $\mathrm{MED}=$ metabolizable energy content of diet; $\mathrm{dMEr}=$ dam metabolizable energy requirement; $\mathrm{dwt}=$ dam weight; $\mathrm{dADG}=$ dam average daily body weight change; MEmk = metabolizable energy of milk production. 


\section{Measurements}

During the experiment, feeds offered and orts were measured daily in order to determine intake. During the period from birth to 14 days of age, daily milk production was recorded during both lactations with an electronic balance (Sartorius $6100 \mathrm{~g} \mathrm{~d}=0.1 \mathrm{~g}$ ). Kids were temporally separated from dams flock during the first 14 days to avoid suckling. Colostrum yield was recorded during the first 1 to 4 days postpartum and then milk yield during the rest of the 14 days post partum. Weaned kids of previous lactation were separated from dams flock to avoid suckling their dams, in order to guarantee colostrum production for the subsequent kidding. Does were milked by hand every day from parturition until day 14 . During this period, kids were each fed with colostrum and milk using a feeding bottle. After feeding, kids were allowed with their dams for five to ten minutes to enhance damkid relationship and avoid rejection of $\operatorname{kid}(\mathrm{s})$ by dam. Everyday, measurements of colostrum and milk yield were recorded thrice: in the morning (8 to 9 o'clock am), afternoon (12 o'clock am to 1 o'clock pm) and evening (6 to 7 o'clock pm). The total daily milk yield was calculated as the sum of three measurements. Feed offered and refusal were measured daily with an electronic balance (KRN5, $\max =5 \mathrm{~kg} \mathrm{~d}=5 \mathrm{~g}$ ) in order to determine the intake.

Does weight were measured using an electronic balance (Kern CH $50 \mathrm{~kg}$, d=50 g $\max =50 \mathrm{~kg}$, version $2.7,2009)$ during two consecutive days: the day of kidding once the placenta had been expelled and the following morning (6 o'clock am) on day 1 of the study. Does weight was recorded once on day seven (07) and twice at the end of the study (i.e. in the evening (6 o'clock pm) on day 13 and in the morning (6 o'clock am) of day 14).

Kids' weight was measured using an electronic balance Baxtran KRN5 (max $=5 \mathrm{~kg}$ $\mathrm{d}=5 \mathrm{~g}$ ). Kid weight was recorded three times: the day of kidding, seven (7) days and twice at the end of the study, in the evening (6 o'clock $\mathrm{pm}$ ) on day 13 and in the morning (6 o'clock am) of day 14. During the experiment, feeds offered and orts were measured daily in order to determine intake.

\section{Chemical analyses}

Representative feed samples (10\%) of dietary components and refusals were collected daily and at the end of the week, a composite sample $(5 \%)$ of each was collected and dried (for DM determination) in the oven at $65{ }^{0} \mathrm{C}$ for $48 \mathrm{~h}$. At the end of the experiment, representative samples of feeds offered and refusals were collected for chemical analyses. Samples of feed offered and orts were analyzed to determine DM, ash, crude protein (Nx6.25), neutral detergent fiber (NDF), acid detergent fiber (ADF), acid detergent lignin (ADL). Dry matter was determined by drying samples in an oven at $60{ }^{0} \mathrm{C}$ for $48 \mathrm{~h}$ until weight became constant. Ash was determined by combusting $1 \mathrm{~g}$ of sample per crucible in a muffle furnace for four hours at $550{ }^{\circ} \mathrm{C}$ (method-942.05 AOAC, 1990). Nitrogen content was determined using the Leco TruMac CNS/NS (LECO Corporation USA, 2012). NDF, ADF and ADL were determined in duplicates using ANKOM-A200/2220 (2052 O’Neil Road, Macedon NY 14502) as described by Van Soest et al. (1991). Neutral detergent fibre content was assayed without a heat stable amylase. Both NDF and ADF were expressed inclusive of residual ash. ADL or lignin (sa) was determined by solubilization of cellulose with sulphuric acid. Hemicellulose was obtained by difference of between NDF and ADF and cellulose was calculated as the difference between ADF and lignin (sa). All these analyses were done in the laboratory of Discipline of Animal Science of University KwaZulu-Natal, Pietermaritzburg.

\section{Statistical analysis}

Data collected during two lactation periods were cleaned, by removing data when kids died particularly during the $2^{\text {nd }}$ experiment, and were analyzed using the General Linear Model of SAS (Statistical Analysis System). Variable included feed 
intake, milk yield, metabolizable energy intake, body weight change of does, and birth weight, final live weight, and live weight gain of kids. The model for analysis was as follows:

$$
\mathrm{Y}_{\mathrm{ijk} l m n o}=\mu+\mathrm{T}_{\mathrm{m}}+\mathrm{A}_{\mathrm{i}}+\mathrm{B}_{\mathrm{j}}+\mathrm{P}_{\mathrm{k}}+\mathrm{S}_{1}+
$$
$\mathrm{W}_{\mathrm{n}}+\mathrm{E}_{\mathrm{ijk} k m n o}$

Where $\mathrm{Y}_{\mathrm{ijklmno}}$ is the independent variable (feed intake, milk yield, metabolizable energy intake, live weight change and live weight gain of kids), $\mu$ is the overall mean, $T_{m}$ is the effect of treatments, $A_{i}$ is the effect of dam ages, $B_{j}$ is the effect of birth type, $P_{k}$ is the effect of parity, $S_{1}$ is the effect of kid sex, $W_{n}$ is the effect of initial body weight and $\mathrm{E}_{\mathrm{ijklmno}}$ is the residual error. The effect of treatment was tested and the means of dam and kid variables were compared between treatments, statistical significance being declared at $\mathrm{P}<0.05$. For the first experiment, linear and quadratic contrasts were used to determine the effect of the treatments. For the second experiment, the effects of the previous level of feeding on these parameters were analysed.

\section{RESULTS}

\section{Dietary ingredient and chemical composition}

The level of feeding differed among T1 to T4 (Table 1). The DM, OM, NDF and ADF contents in refusals were higher than in feeds offered (Table 2).

\section{Effect of feeding levels on feed intake and production performance of dams}

Feed intake varied $(\mathrm{P}<0.001)$ among treatments (Table 3). Feed intake increased linearly $(\mathrm{P}<0.001)$ but not in a quadratic fashion $(\mathrm{P}>0.05)$ with increasing feeding levels. Dams with twins had higher DMI than dams with singles ( 731 versus $617, \mathrm{P}<0.05$ ). The metabolizable energy intake of dams (dMEi) had the same trend like DMI and varied $(\mathrm{P}<0.001)$ among treatments (Table 3$)$. Birth type had an influence on dMEi where dam with twins consumed higher ME (6.68 versus $5.60, \mathrm{P}<0.05)$ than with single. Kids' variables did not affect $(\mathrm{P}>0.05)$ DMI of dams.
Milk yield did not vary $(\mathrm{P}>0.05)$ among treatments (Table 3), though it increased $(\mathrm{P}<0.01)$ linearly but not in a quadratic $(\mathrm{P}>0.05)$ fashion. The dam initial weight affected $(\mathrm{P}<0.05)$ milk yield while other dam and kid variables had no effect. Milk production would increase by $9.42 \mathrm{ml}$ $(\mathrm{SE}=3.63, \mathrm{P}<0.5)$ per day per unit change $(1$ $\mathrm{kg}$ ) in body weight. Dam final live weight (dfwt) and dam weight change (dwtc) were not affected by treatments (Table 3). All kid and dam variables except dam initial weight did not affect $(\mathrm{P}>0.05)$ dfwt and dwtc.

Effect of feeding levels of dams on milk and metabolizable energy intakes and production performances of kids

Milk intake did not vary $(\mathrm{P}>0.05)$ among treatments while the metabolizable energy (ME) intake differed $(\mathrm{P}<0.05)$ (Table 4). Age, parity, dam initial weight (diwt) and kid sex (ksex) did not affect ( $P>0.05$ ) kid milk intake. However, birth type affected (124.3 $\pm 14.75, \quad \mathrm{P}<0.001)$ kid milk intake $(\mathrm{P}<0.001)$ and kid ME intake $(\mathrm{P}<0.001)$ where single born consumed higher milk and ME than twins (330.83 versus $206.52 \mathrm{~g} / \mathrm{day}$, $\mathrm{P}<0.001)$ and $(0.909$ versus $0.584 \mathrm{MJ} /$ day, $\mathrm{P}<0.001)$ respectively. Kid initial weight (kiwt) $(73.12 \pm 25.24, \mathrm{P}<0.01)$ affected also kid milk intake suggesting that every $1 \mathrm{~kg}$ change in kid weight would increase milk intake by 73 g. Kid's milk and metabolizable energy intakes increased linearly $(\mathrm{P}<0.05)$ but not in a quadratic fashion with feeding levels of dams.

Kid final weight was not affected $(\mathrm{P}>0.05)$ by treatments (Table 4$)$, age, parity, dam initial weight (diwt) or kid sex (ksex). However, it was highly affected $(\mathrm{P}<0.001)$ by birth type $(0.38 \pm 0.06, \mathrm{P}<0.001)$ where single born and twins had final weight of $2.39 \mathrm{~kg}$ and $1.88 \mathrm{~kg}$ respectively. Similarly, kid initial weight (kiwt) strongly affected kid final weight $(0.98 \pm 0.10, \mathrm{P}<0.001)$.

The kid average daily body weight gain were similar $(\mathrm{P}>0.05)$ among treatments (Table 4$)$ and were not affected $(\mathrm{P}>0.05)$ by all dam variables and kid variables. However, it was highly affected $(\mathrm{P}<0.001)$ by type of 
birth $(29.07 \pm 4.79, \quad \mathrm{P}<0.001)$ where singles gained more weight than twins (54 versus 28 $\mathrm{g} / \mathrm{d})$. No other effect was significant $(\mathrm{P}>0.05)$.

\section{Effect of previous feeding levels on production performances of dams}

Feed intake, metabolizable energy intake and daily milk yield were not affected $(\mathrm{P}<0.05)$ by previous levels of feeding (treatments), age, parity and birth type (Table 5). However, previous treatments strongly affected $(\mathrm{P}<0.001)$ final weight and daily weight change of dam. Age and birth type affected $(\mathrm{P}<0.05)$ final live weight of dam whereas live weight change of dam was heavily affected $(\mathrm{P}<0.001)$ by age, birth type and parity.

\section{Effect of previous levels of feeding dams on} kids' milk and metabolizable energy intakes

The previous levels of feeding did not affect $(\mathrm{P}>0.05)$ kids' milk intake whereas the metabolizable energy intake varied $(\mathrm{P}<0.01$; Table 6). Kid final weight was affected $(\mathrm{P}<0.05)$ by previous treatment while the kid weight gain was not.

\section{Colostrum phase}

The colostral period during two subsequent lactations varied from 1 to 4 days with means of 2.83 (RMSE=0.54) (Table 7). The level of feeding, parity, type of birth and the interactions treatment $x$ type of birth did not affect $(\mathrm{P}>0.05)$ the duration of colostrum. However, age affected $(\mathrm{P}<0.05)$ the duration of colostrum where the colostrum phase increased from primiparous to aged does. Similarly, the parity interacted with birth type to affect $(\mathrm{P}<0.05)$ colostral duration.

Metabolizable energy intake and requirements of dams and kids according to AFRC and NRC systems

The ME intake of dams and kids and their ME requirements for two experimental data set are shown in Table 8. The average value of dams' metabolizable energy intake was close to metabolizable energy requirement of AFRC (dMEr_AFRC) but lower than that of NRC (dMEr_NRC). Concerning kids, the average value of metabolizable energy intake was similar to metabolizable energy requirement (MEr) of AFRC but much lower than that of NRC.

Table 1: Dietary ingredient and chemical composition.

\begin{tabular}{lllll}
\hline & Ration & \multicolumn{4}{c}{ Diet } \\
\cline { 3 - 5 } Ingredient (g of DM) & T1 & T2 & T3 & T4 \\
\hline CUTMS & 385 & 384 & 385 & 385 \\
GH & 308 & 307 & 308 & 308 \\
WB & 230 & 231 & 231 & 231 \\
CSC & 77 & 77 & 77 & 77 \\
Total & 1000 & 1000 & 1000 & 1000 \\
Chemical composition & & & & \\
N (g/kg DM) & 16.93 & 16.93 & 16.93 & 16.93 \\
ME of diet (MJ/kg DM) & 9.24 & 9.24 & 9.24 & 9.24 \\
Rationing & & & & \\
Target milk production (g) & 200 & 400 & 600 & 800 \\
Rationing level (g/day) & 842 & 934 & 1079 & 1300 \\
Feeding level & 0.65 & 0.72 & 0.83 & 1 \\
\hline T: treatment; CUTMS: crushed and urea treated millet stover; GH: groundnut haulms; WB: wheat bran; CSC: cottonseed \\
cake; ME: metabolisable energy.
\end{tabular}


Table 2: Chemical composition of feeds offered and refusals (g/kg DM).

\begin{tabular}{llcccc}
\hline \multirow{2}{*}{ Parameters } & Feed & T1 & T2 & T3 & T4 \\
\cline { 3 - 6 } DM & Offered & 822 & 822 & 822 & 822 \\
& refusal & 965 & 965 & 965 & 965 \\
\multirow{2}{*}{ OM } & Offered & 916 & 916 & 916 & 916 \\
& refusal & 933 & 947 & 940 & 959 \\
\multirow{2}{*}{ NDF } & Offered & 613 & 613 & 613 & 613 \\
& refusal & 713 & 715 & 672 & 726 \\
\multirow{2}{*}{ ADF } & Offered & 385 & 385 & 385 & 385 \\
& refusal & 510 & 519 & 480 & 531 \\
\hline
\end{tabular}

T: treatment; DM: Dry matter; OM: Organic matter, NDF: Neutral detergent fibre; ADF: Acid detergent fibre.

Table 3: Effect of levels of feeding dams on production performance of lactating does.

\begin{tabular}{|c|c|c|c|c|c|c|c|}
\hline Treatment & $\mathbf{n}$ & $\begin{array}{c}\text { Dam } \\
\text { initial } \\
\text { weight } \\
\end{array}$ & $\begin{array}{c}\text { DM intake } \\
\text { MI (g) }\end{array}$ & $\begin{array}{c}\text { ME intake } \\
\text { (MJ/day) }\end{array}$ & $\begin{array}{c}\text { Daily milk } \\
\text { yield (g) }\end{array}$ & $\begin{array}{c}\begin{array}{c}\text { Final } \\
\text { weight } \\
(\mathrm{kg})\end{array} \\
\end{array}$ & $\begin{array}{c}\text { Daily } \\
\text { weight } \\
\text { change (g) }\end{array}$ \\
\hline $\mathrm{T} 1$ & 10 & 22.09 & $501 \mathrm{~d}$ & $4.63 b$ & $332 \mathrm{a}$ & 20.81 & -168 \\
\hline $\mathrm{T} 2$ & 10 & 23.30 & $606 \mathrm{bcd}$ & $5.59 \mathrm{~b}$ & $376 a$ & 21.41 & -125 \\
\hline $\mathrm{T} 3$ & 10 & 23.02 & $731 \mathrm{ab}$ & $6.75 \mathrm{a}$ & $447 \mathrm{a}$ & 21.51 & -118 \\
\hline $\mathrm{T} 4$ & 10 & 25.75 & $824 a$ & $7.61 \mathrm{a}$ & $510 \mathrm{a}$ & 21.34 & -130 \\
\hline \multicolumn{8}{|c|}{ Variation sources } \\
\hline RMSE & & & 116.07 & 1.06 & 172.39 & 1.17 & 84.20 \\
\hline Treatment & & & $* * *$ & $* * *$ & NS & NS & NS \\
\hline Age & & & NS & NS & NS & NS & NS \\
\hline Parity & & & NS & NS & NS & NS & NS \\
\hline Typeb & & & $*$ & $*$ & NS & NS & NS \\
\hline diwt & & & NS & NS & $*$ & $* * *$ & $* * *$ \\
\hline kiwt & & & NS & NS & NS & NS & NS \\
\hline ksex & & & NS & NS & NS & NS & NS \\
\hline Linear & & & $* * *$ & $* * *$ & $* *$ & NS & NS \\
\hline Quadratic & & & NS & NS & NS & NS & NS \\
\hline
\end{tabular}


Table 4: Effect of levels of feeding dams on post-natal performance of kids.

\begin{tabular}{|c|c|c|c|c|c|c|}
\hline Treatment & $\mathbf{n}$ & $\begin{array}{c}\text { Kid initial } \\
\text { wt (kg) }\end{array}$ & $\begin{array}{l}\text { Kid milk } \\
\text { intake (g) }\end{array}$ & $\begin{array}{c}\text { Kid ME } \\
\text { intake } \\
\text { (MJ/day) }\end{array}$ & $\begin{array}{c}\text { Kid final wt } \\
(\mathrm{Kg})\end{array}$ & $\begin{array}{l}\text { Kid wt } \\
\text { gain }(g)\end{array}$ \\
\hline $\mathrm{T} 1$ & 10 & 1.67 & $242 \mathrm{a}$ & $0.683 b$ & $2.09 \mathrm{a}$ & $37.40 \mathrm{a}$ \\
\hline $\mathrm{T} 2$ & 10 & 1.80 & $303 a$ & $0.846 a b$ & $2.42 \mathrm{a}$ & $51.00 \mathrm{a}$ \\
\hline $\mathrm{T} 3$ & 10 & 1.61 & $307 a$ & $0.762 \mathrm{ab}$ & $2.10 \mathrm{a}$ & $41.63 \mathrm{a}$ \\
\hline $\mathrm{T} 4$ & 10 & 1.76 & $305 a$ & $0.885 \mathrm{a}$ & $2.29 \mathrm{a}$ & $51.24 \mathrm{a}$ \\
\hline \multicolumn{7}{|c|}{ Variation sources } \\
\hline RMSE & & & 70.74 & 0.32 & 0.37 & 19.56 \\
\hline Treatment & & & NS & $*$ & NS & NS \\
\hline Age & & & NS & $*$ & NS & NS \\
\hline Parity & & & NS & NS & NS & NS \\
\hline Typeb & & & $* * *$ & $* * *$ & $* * *$ & $* * *$ \\
\hline diwt & & & NS & NS & NS & NS \\
\hline kiwt & & & $* *$ & $* *$ & $* * *$ & NS \\
\hline ksex & & & NS & NS & NS & NS \\
\hline Linear & & & $*$ & $*$ & NS & NS \\
\hline Quadratic & & & NS & NS & NS & NS \\
\hline
\end{tabular}

T: treatment; n: number of observation; Typeb: birth type; diwt: dam initial weight; change; kiwt: kid initial weight; ksex; kid sex; wt: weight; ME: metabolisable energy; Means in the column with the same lowercase letter are not significantly different at $\mathrm{P}<0.05$; RMSE: Root mean square error; NS $(\mathrm{P}>0.05)$; $(\mathrm{P}<0.05)$; ** $(\mathrm{P}<0.01)$; *** $(\mathrm{P}<0.001)$.

Table 5: Effect of previous levels of feeding dams on production performance of lactating does.

\begin{tabular}{|c|c|c|c|c|c|c|c|}
\hline Ptreatment & $\mathbf{n}$ & $\begin{array}{c}\text { Dam initial } \\
\text { weight } \\
(\mathrm{kg})\end{array}$ & $\begin{array}{c}\text { DM } \\
\text { intake } \\
\text { (g/day) }\end{array}$ & $\begin{array}{c}\text { ME } \\
\text { intake } \\
\text { (MJ/day) }\end{array}$ & $\begin{array}{c}\text { Daily } \\
\text { milk } \\
\text { yield (g) }\end{array}$ & $\begin{array}{c}\text { Final } \\
\text { weight } \\
(\mathrm{kg})\end{array}$ & $\begin{array}{l}\text { Daily weight } \\
\text { change } \\
\text { (g) }\end{array}$ \\
\hline $\mathrm{T} 1$ & 4 & 22.57 & $839 a$ & $7.75 \mathrm{a}$ & $408 \mathrm{a}$ & $21.89 \mathrm{c}$ & $44 a$ \\
\hline $\mathrm{T} 2$ & 2 & 24.31 & $875 a$ & $8.09 \mathrm{a}$ & $426 \mathrm{a}$ & $21.74 \mathrm{c}$ & $-110 c$ \\
\hline $\mathrm{T} 3$ & 3 & 29.73 & $861 \mathrm{a}$ & $7.96 a$ & $371 \mathrm{a}$ & $26.28 \mathrm{a}$ & $-160 d$ \\
\hline $\mathrm{T} 4$ & 8 & 27.89 & $837 \mathrm{a}$ & $7.73 a$ & $364 a$ & $24.66 b$ & $-108 c$ \\
\hline \multicolumn{8}{|c|}{ Variation sources } \\
\hline RMSE & & & 203.11 & 1.87 & 153.12 & 1.81 & 0.04 \\
\hline Ptreatment & & & NS & NS & NS & $* * *$ & $* * *$ \\
\hline Age & & & NS & NS & NS & $*$ & $* * *$ \\
\hline Parity & & & NS & NS & NS & NS & $* * *$ \\
\hline Typeb & & & NS & NS & NS & $* *$ & $* * *$ \\
\hline
\end{tabular}

T: treatment; Typeb: birth type; diwt: dam initial weight; Ptreatment: previous treatment; DM: dry matter; ME: metabolizable energy; Means in the column with the same lowercase letter are not significantly different at $\mathrm{P}<0.05$; RMSE: Root mean square error; NS $(\mathrm{P}>0.05)$. 
Table 6: Effect of previous levels of feeding dams on post-natal performance of kids.

\begin{tabular}{|c|c|c|c|c|c|c|}
\hline Ptreatment & $\mathbf{n}$ & $\begin{array}{c}\text { Kid initial } \\
\text { wt (kg) }\end{array}$ & $\begin{array}{c}\text { Kid ME } \\
\text { intake } \\
\text { (MJ/day) }\end{array}$ & $\begin{array}{l}\text { Kid milk } \\
\text { intake (g) }\end{array}$ & $\begin{array}{c}\text { Kid final wt } \\
(\mathrm{kg})\end{array}$ & $\begin{array}{c}\text { Kid wt gain } \\
\text { (g) }\end{array}$ \\
\hline $\mathrm{T} 1$ & 4 & 1.60 & $1.168 \mathrm{a}$ & $167 \mathrm{a}$ & $2.58 \mathrm{a}$ & $71.87 \mathrm{a}$ \\
\hline $\mathrm{T} 2$ & 2 & 1.37 & $0.392 b$ & $133 \mathrm{a}$ & $1.39 \mathrm{~b}$ & $9.61 \mathrm{a}$ \\
\hline $\mathrm{T} 3$ & 3 & 1.68 & $0.572 b$ & $145 \mathrm{a}$ & $2.07 \mathrm{a}$ & $27.52 \mathrm{a}$ \\
\hline $\mathrm{T} 4$ & 8 & 1.40 & $1.049 \mathrm{a}$ & $158 \mathrm{a}$ & $2.31 \mathrm{a}$ & $57.53 \mathrm{a}$ \\
\hline \multicolumn{7}{|c|}{ Variation sources } \\
\hline RMSE & & & 0.342 & 100.55 & 0.144 & 12.82 \\
\hline Ptreatment & & & $* *$ & NS & $*$ & NS \\
\hline Age & & & NS & NS & NS & NS \\
\hline Parity & & & NS & NS & NS & NS \\
\hline Typeb & & & NS & NS & NS & NS \\
\hline Sex & & & NS & NS & NS & NS \\
\hline
\end{tabular}

Table 7 : Factors affecting the duration of colostrum phase.

\begin{tabular}{lccccc}
\hline Treatment & n & Colostrum phase & Age & n & Colostrum phase \\
\hline T1 & 17 & $2.88^{\mathrm{a}}$ & 1 & 5 & $2.2 \mathrm{c}$ \\
T2 & 16 & $2.50^{\mathrm{a}}$ & 2 & 7 & $2.85 \mathrm{bc}$ \\
$\mathrm{T} 3$ & 22 & $2.95^{\mathrm{a}}$ & 3 & 23 & $2.65 \mathrm{bc}$ \\
$\mathrm{T} 4$ & $3.00^{\mathrm{a}}$ & 4 & 35 & $2.83 \mathrm{bc}$ \\
& 27 & & 7 & 3 & $3.67 \mathrm{a}$ \\
\hline
\end{tabular}

Variation sources

$\begin{array}{lc}\text { RMSE } & 0.56 \\ \text { Mean } & 2.83 \\ \text { Treatment } & \text { NS } \\ \text { Age } & * \\ \text { Parity } & \text { NS } \\ \text { Typeb } & \text { NS } \\ \text { Teatment*Typeb } & \text { NS } \\ \text { Parity*Typeb } & *\end{array}$

T: treatment; n: number of observations; Typeb: birth type; Means in the column with the same lowercase letter are not significantly different at $\mathrm{P}<0.05$; RMSE: Root mean square error; NS $(\mathrm{P}>0.05)$; $(\mathrm{P}<0.05)$; ** $(\mathrm{P}<0.01)$; *** $(\mathrm{P}<0.001)$. 
Table 8 : Observed metabolisable energy intakes of dams and kids compared with requirements according to AFRC (1993) and NRC (2007) systems.

\begin{tabular}{|c|c|c|c|}
\hline Experiments & Kidding 1 & Kidding 2 & Average \\
\hline $\mathrm{n}$ & 40 & 24 & - \\
\hline dMEi (MJ/d) & 6.128 & 7.518 & 6.478 \\
\hline dMEr_AFRC (MJ/d) & 5.768 & 6.724 & 6.009 \\
\hline dMEr_NRC (MJ/d) & 7.697 & 9.022 & 8.030 \\
\hline kME intake (MJ/d) & 0.794 & 0.822 & 0.808 \\
\hline kMEr_AFRC (MJ/d) & 0.827 & 0.802 & 0.814 \\
\hline kMEr_NRC (MJ/d) & 1.540 & 1.500 & 1.520 \\
\hline kMEint $\quad\left(\mathrm{KJ} / \mathrm{kg} \mathrm{BW}^{0.75}\right)$ & 440 & 551 & 495.5 \\
\hline
\end{tabular}

\section{DISCUSSION}

The linear increase of dry matter intake from treatments $\mathrm{T} 1$ to $\mathrm{T} 4$ may be explained by increasing levels of feeding. Similar findings were observed by others (Malau-Aduli et al., 2004; Greyling et al., 2004; Kinuthia et al., 2007) who reported increased dry matter intake (DMI) when goats were offered more feeds. DMI of goats is influenced by several factors, namely feed quality, coarseness, palatability of feed, roughage concentrate ratio, animal behaviour and physiological stage of goats. The increase of dams' metabolizable energy intake (dMEi) with increasing level of feeding may be attributed to DMI of dams since the dMEi was related to dry matter of feeds. This is the reason why the dMEi increased similarly to DMI which is similar to others (Kinuthia et al., 2007). These $\mathrm{dMEi}$ were above the minimum requirement of maintenance estimated at $4.52 \mathrm{MJ} / \mathrm{d}$ (Sahlu et al., 2004) for goats weighing $23 \mathrm{~kg}$.

The lack of treatment effect on milk yield despite the linear increase in dry matter and metabolizable energy intakes may be explained by the energy mobilized from body tissue for milk production at the early stage of lactation. However, Greyling et al. (2004) reported effect of level of nutrition on milk production of indigenous and Boer goats in South Africa. Results on milk yield in the present study are similar to those obtained by others (Zahraddeen et al., 2009a; Otaru et al., 2011) on the same breed. However, MalauAduli et al. (2004) reported lower (270 g/day) and higher (620 g/day) milk yield values than the present study with unsupplemented and supplemented (with concentrate) treatments, respectively. Additionally, Sangaré and Pandey (2000) reported higher values (700$850 \mathrm{~g} /$ day) in early lactation (two first weeks) on Sahelian goats in Mali.

Although only the effect of treatment on kMEint was significant, the linear effect of T1 to T4 was not significant for milk intake. This variation of kMEint can be attributed to both birth type and variation in kid initial weight among treatments which would impact on kid milk intake or the kMEint derived from milk intake in the present study. This linear effect of treatments on kMEint may also be due to differences in duration of colostrum phase which had higher ME content than normal milk and kid which consumed colostrum during more days may consume 
more energy than the one which had less days on colostrum.

The influence of previous levels of feeding on dams' final weight and body weight change could be explained by increased feed intake and body weight gain of does in the previous experiment before subsequent kidding where does gained more weight with graded levels of feeding during the last three months of pregnancy. It has been recognized that the body condition scores and stage of lactation influence the energy value of body weight change of lactating animals especially in early and late lactation where body weight change can be large. Thus, during early lactation in accordance with the present study, does might mobilize fat and protein from their body reserves to satisfy milk production and this has repercussion on body weight and body weight change that were observed.

The observed metabolizable energy intake of kids in the present study was close to $\mathrm{ME}$ requirements of AFRC system whereas the ME requirements of NRC were greater than that observed. Using the NRC requirements will satisfy requirement for more animals in a herd but may overfeed more animals. Similar results were observed with metabolizable energy requirements for dams, where the ME requirements based on AFRC system were closer to ME values observed compared with NRC system which were greater than $\mathrm{ME}$ observed. The differences between ME intake and required could be attributed to type of breed, type of production, feeding system, and age or stage of animals. Observed mean values of ME intake of kids in experiment $1\left(1^{\text {st }}\right.$ kidding of the study $)$ and experiment 2 (the subsequent kidding) were 440 and $551 \mathrm{~kJ} / \mathrm{kwt}^{0.75}$ respectively, but overlapped results $\left(485 \mathrm{~kJ} / \mathrm{kwt}^{0.75}, \quad 13.4\right.$ $\mathrm{KJ} / \mathrm{ADG}$ ) of Luo et al. (2004) on suckling kids. However, values of MEint observed were lower than those obtained by Sahlu et al. (2004) on suckling kids (1.424 MJ/d) of $50 \mathrm{~g}$ average daily gain (ADG). It is important to note that in some studies, dietary ME was calculated based on feed digestibility through fecal collection whereas others used markers to estimate fecal output. In the present study, ME intake was based on milk intake and feed intake of nursing kids and their dams, respectively. Nonetheless, according to their similarities, to estimate the metabolizable energy requirements of suckling kids and does of Red Maradi goat, it appears rationing based on the NRC system would be more generous than based on AFRC system.

The high DM, OM, NDF and ADF contents of refusals may be explained by differences in physical and chemical characteristics of feeds (Abdou et al., 2017) due to feeding behaviour of goats known to select feeds based on prehension ease, nutrient content and post-ingestive effects. This is in agreement with other works (Provenza et al., 2003; Basha et al., 2009; Glasser et al., 2012; Tshibangu et al., 2014).

The influence of birth type on DMI could be attributed to high demand of energy by dam with twins compared with those with single to satisfy kids' milk intake and their maintenance. The significant effect of birth type on milk yield is similar to the findings of other researchers (Zahraddeen et al., 2009a; Sanogo et al., 2012). However, Akpa et al. (2001) reported that birth type did not influence milk yield. The effect of dam initial weight on milk yield is similar to the findings of Sangaré and Pandey (2000) on Sahelian goats. The variation in milk yield compared with other studies could be due to differences in nutritive value of diets, breed, parity, body weight of does, frequency and milking methods.

All groups of lactating does during the first two weeks postpartum lost body weight in agreement with Greyling et al. (2004) using indigenous and Boer goats in South Africa. The significant effect of dam initial weight (diwt) on both dam final weight (dfwt) and dam weight change (dwtc) is in agreement with other studies (Fedele et al., 2002; Otaru et al., 2011; Casals et al., 2006). This loss of body weight corrects for the lower feed intake after kidding and therefore does mobilize own energy reserves to satisfy the extra energy 
requirement for milk production at this particular stage of lactation. Djibrillou et al. (1998) attributed body weight loss of lactating does to the unbalanced energy requirement and energy provided in the diet, whereas Casals et al. (2006) attributed this to the decrease of DMI.

The significant effect of dam's age on kid metabolizable energy intake (kMEint) could be explained by the duration of colostral phase which differed according to dam's age or the ME in colostrum is higher than that of the normal milk. Thus, kid born by aged dam could consume more ME than kids of young does. The influence of birth type on kid milk intake and kMEint may be due to the fact that dam's milk is shared between twins born kids. This was the reason why kid milk and ME intakes of single borns were higher than those of twins which would have repercussions on kids' final weight and body weight gain in spite of the superiority of milk yield of dam giving twins. This similarity of trend is due to the fact that kMEint derived from milk intake. Furthermore, single born kids were heavier than twins born kids at kidding, and the present study showed the effect of kid initial weight (kiwt) on kid milk intake. Both of these results are in agreement with Sangaré and Pandey (2000) where kid initial weight affected milk intake and consequently the final live weight. Kids' birth weights in the present study were close to those reported by Muktar et al. (2011) on the same breed. However, lower values were obtained by Malau-Aduli et al. (2004) on the same breed in Nigeria and higher values by Sangaré and Pandey (2000) on Sahelian goats in Mali, by Mahmoud et al. (2012) on Damascus goats' kids in Sudan and by Castro et al. (2009) on Majorera goat kids in Spain. This variation in kid birth weight could be attributed to differences in livestock system, diets and breeds. The effect of kid initial weight (kiwt) on kid final weight (kfwt) is in agreement with other works (Sangaré and Pandey, 2000; Al-Shorepy et al., 2002; Andries, 2013). The influence of birth type on kfwt may be due to the kiwt and kid milk intake (as explained above), where a single born kid was heavier than twins and consumed more milk than twins which had repercussion on kfwt during early lactation. The influence of birth type on kid weight gain (kwtg) corroborates the findings of Zahraddeen (2009b).

The influence of age and birth type on body weight and body weight change of dam at the subsequent lactation may be explained by the characteristic of Red Maradi goat which is reputed as a prolific breed in West Africa (Djariri, 2005) of which prolificacy is influenced by parity (age). According to Marichatou et al. (2002), 36.48\% of twins born were observed with Red Maradi goat.. As parity is highly correlated with age and naturally multiparous does are heavier than young ones. This analogy may be explained by the influence of age and birth type on body weight and body weight change.

The length of colostrum phase ( 1 to 4 days) is in agreement with some works on other breeds (Gajdusek et al., 2001; Kracmar et al., 2002; Kráčmar et al., 2003; Argüello et al., 2004). These authors stipulated that variations in minerals contents of colostrum occurred between 48 and 96 hours and in this present study, distinction between colostrum and milk was based on the yellowish colour characteristic of colostrum. In the present study, the parity interacted with birth type to affect colostrum duration/production which is also supported by Romero et al. (2013).

\section{Conclusion}

The levels of feeding dams did not affect the production performance of lactating Red Maradi goat and their kids during the first 14 days postpartum. The previous levels of feeding dams had impacted on body weight of dams and kids. The metabolizable energy intake of kids was closer to ME requirements based on AFRC compared with that of NRC system. Kids nurse by does on increasing feeding levels consumed more milk and tended to have a better body weight. To overcome the ME requirements of kids and lactating does of Red Maradi goats, the requirements of NRC system should be used. 


\section{COMPETING INTERESTS}

The authors declare that they have no competing interests.

\section{AUTHORS' CONTRIBUTIONS}

NA: Implementation of experiments, laboratory analysis, writing manuscript; ASG: Assistance on field work, observations on manuscript; IVN: Assistance on laboratory analysis and statistical analysis, contribution to improve the language of the manuscript and editing the manuscript.

\section{ACKNOWLEDGEMENTS}

The authors wish to express their gratitude to the Discipline of Animal and Poultry Sciences, SAEES, UKZN, Rep. South Africa for providing materials and equipment of their laboratory.

\section{REFERENCES}

Abdou N, Gouro AS, Nsahlai IV. 2017. Nutritional Characteristics of Available Feed Resources in Maradi Area of Niger. Animal Nutrition and Feed Technology, 17: 229-243. DOI: 10.5958/0974181X.2017.00023.3

AFRC. 1993. Energy and Protein Requirements of Ruminants. An advisory manual prepared by the AFRC Technical Committee on Responses to Nutrients. Wallingford, $\mathrm{CAB}$ International:UK.:

Akinsoyinu A, Tewe O, Ngere L, Mba A. 1981. Milk composition and yield of the Red Sokoto (Maradi) goats in Nigeria. Tropical Animal Production, 6(2): 186.

Akpa G, Asiribo E, Oni O, Alawa J. 2001. The influence of non-genetic factors on the shape of lactation curves in Red Sokoto goats. Animal Science-Glasgow, 72: 233240.

Al-Shorepy SA, Alhadrami GA, Abdulwahab K. 2002. Genetic and phenotypic parameters for early growth traits in Emirati goat. Small Ruminant Research, 45(3): 217-223. DOI: $10.1016 / S 0921-$ 4488(02)00110-4

Andries KM. 2013. Growth and Performance of Meat Goat Kids from Two Seasons of
Birth in Kentucky. Sheep and Goat Research Journal, 28.

Argüello A, Castro N, Capote J, Tyler J, Holloway N. 2004 Effect of colostrum administration practices on serum IgG in goat kids. Livestock Production Science, 90: 235-239.

Basha N, Scogings P, Nsahlai I. 2009. Diet selection by Nguni goats in the Zululand Thornveld. South African Journal of Animal Science, 39: 33-36.

Casals R, Caja G, Pol M, Such X, Albanell E, Gargouri A, Casellas J. 2006. Response of lactating dairy ewes to various levels of dietary calcium soaps of fatty acids. Animal Feed Science and Technology, 131: 312-332. DOI: https://doi.org/ 10.1016/ j.anifeedsci.2006.06.014

Castro N, Capote J, Morales-delaNuez A, Rodríguez C Argüello A. 2009. Effects of newborn characteristics and length of colostrum feeding period on passive immune transfer in goat kids. Journal of Dairy Science, 92: 1616-1619. DOI: $\quad$ https://doi.org/10.3168/jds.20081397

Czerkawski JW. 1986. An Introduction to Rumen Studies. Elsevier.

Djariri B. 2005. Monographie de la chèvre rousse de Maradi, 27.

Djibrillou OA, Pandey VS, Gouro SA, Verhulst A. 1998. Effect of urea-treated or untreated straw with cotton seed on performances of lactating Maradi (Red Sokoto) goats in Niger. Livestock Production Science, 55: 117-125. DOI: $\quad$ https://doi.org/10.1016/S03016226(98)00130-4

Fedele V, Claps S, Rubino R, Calandrelli M, Pilla A. 2002. Effect of free-choice and traditional feeding systems on goat feeding behaviour and intake. Livestock Production Science, 74: 19-31. DOI: https://doi.org/10.1016/S03016226(01)00285-8

Gajdusek S, Kracmar S, Jelinek P, Kuchtik J. 2001. Changes in protein content and correlations between contents of amino acids of goat's colostrum during the first 
72 hours after parturition. Czech Journal of Animal Science-UZPI (Czech Republic).

Glasser T, Landau S, Ungar E, Perevolotsky A, Dvash L, Muklada H, Kababya D, Walker J. 2012. Foraging selectivity of three goat breeds in a Mediterranean shrubland. Small Ruminant Research, 102: 7-12. DOI: https://doi.org/10.1016/ j.smallrumres.2011.09.009

Greyling J, Mmbengwa V, Schwalbach L, Muller T. 2004. Comparative milk production potential of Indigenous and Boer goats under two feeding systems in South Africa. Small Ruminant Research, 55: 97-105. DOI: https://doi.org/10.1016/j.smallrumres.2003 .11 .014

Kinuthia M, Wanyoike M, Gachuiri C, Wakhungu J. 2007. Effect of supplementing weaner goats with graded levels of Calliandra calothyrsus and Lucerne (Medicago sativa) on feed intake and weight gain. Livestock Research for Rural Development, 19.

Kráčmar S, Gajdůšek $\mathrm{S}$, Jelínek $\mathrm{P}$, Illek $\mathrm{J}$. 2003. Changes in contents of some macroand microelements in goat's colostrum within the first $72 \mathrm{~h}$ after parturition. Small Ruminant Research, 49: 213-218. DOI: https://doi.org/10.1016/S0921-4488(03) 00073-7

Kracmar S, Gajdusek S, Kuchtík J, Jelínek P, Minarik B. 2002. Changes in parameters of nutritional value of goat colostrum within 72 hours afrer parturition. Acta Universitatis Agriculturae et Silviculturae Mendelianae Brunensis (Czech Republic).

Luo J, Goetsch A, Sahlu T, Nsahlai I, Johnson Z, Moore J, Galyean M, Owens F, Ferrell C. 2004. Prediction of metabolizable energy requirements for maintenance and gain of preweaning, growing and mature goats. Small Ruminant Research, 53: 231252. DOI: https://doi.org/10.1016/ j.smallrumres.2004.04.006

Mahmoud N, El Zubeir I, Fadlelmoula A. 2012. Colostrum composition and performance of Damascus goats raised under Sudan conditions. Wudpecker J. Agr. Res, 1: 341-345.

Malau-Aduli BS, Eduvie L, Lakpini C, Malau-Aduli AEO. 2004. Crop-residue supplementation of pregnant does influences birth weight and weight gain of kids, daily milk yield but not the progesterone profile of Red Sokoto goats. Reproduction Nutrition Development, 44: 111-121.

Marichatou H, Mamane L, Banoin M, Baril M. 2002. Performances zootechniques des caprins au Niger: étude comparative de la chèvre rousse de Maradi et de la chèvre à robe noire dans la zone de Maradi. Revue d'Elevage et de Médecine Vétérinaire des Pays Tropicaux, 55. DOI: https://doi.org/10.19182/remvt.9850

Muktar Y, Aminu I, Midau A. 2011. The effect of different supplements on birth weight and kid growth on Red Sokoto goats in Adamawa State, Nigeria. Global Journal of Science Frontier Research, 11.

Nnadi P, Kamalu T, Onah D. 2007. Effect of dietary protein supplementation on performance of West African Dwarf (WAD) does during pregnancy and lactation. Small Ruminant Research, 71: 200-204. DOI: https://doi.org/10.1016/ j.smallrumres.2006.06.007

NRC. 2007. Nutrient Requirements of Small Ruminants. The National Academies Press: Washington, D.C.

Nsahlai I, Apaloo J. 2007. On the suitability of Illius and Gordonl's model for simulating the intake and digestibility of roughage diets by ruminants. South African Journal of Animal Science, 37: 275-289. DOI: http://dx.doi.org/10.4314/ sajas.v37i4.4101

Otaru S, Adamu A, Ehoche O, Makun H. 2011. Effects of varying the level of palm oil on feed intake, milk yield and composition and postpartum weight changes of Red Sokoto goats. Small Ruminant Research, 96: 25-35. DOI: https://doi.org/10.1016/j.smallrumres.2010 .11 .004 
Pamo ET, Boukilq B, Tendonkeng F. 2007. Goat production research in Africa: a sign post review for research in the new millennium. Int. J. Biol. Chem. Sci, 1(1): 76-89. DOI: http://dx.doi.org/10.4314/ ijbcs.v1i1.39702

Petros A, Aragaw K, Shilima B. 2014. Preweaning kid mortality in Adamitulu Jedokombolcha District, Mid Rift Valley, Ethiopia. Journal of Veterinary Medicine and Animal Health, 6: 1-6. DOI: 10.5897/JVMAH13.0211

Provenza FD, Villalba JJ, Dziba L, Atwood SB, Banner RE. 2003. Linking herbivore experience, varied diets, and plant biochemical diversity. Small ruminant research, 49: 257-274. DOI: https://doi.org/10.1016/S0921-4488 (03) 00143-3

RGAC-Niger. 2007. Recensement Général de l'Agriculture et du Cheptel: Productivité $\mathrm{du}$ Cheptel, Enclaves Pastorales et Transect. Ministère du Développement Agricole et Ministère de Production Animale, $\mathbf{5}$.

Romero T, Beltrán M, Rodríguez M, De Olives AM, Molina M. 2013. Short communication: Goat colostrum quality: Litter size and lactation number effects. Journal of dairy science, 96: 7526-7531. DOI: https://doi.org/10.3168/jds.20136900

Sahlu T, Goetsch A, Luo J, Nsahlai I, Moore J, Galyean M, Owens F, Ferrell C, Johnson Z. 2004. Nutrient requirements of goats: developed equations, other considerations and future research to improve them. Small Ruminant Research, 53: 191-219. DOI: https://doi.org/ 10.1016/j.smallrumres.2004.04.001

Sangaré M, Pandey V. 2000. Food intake, milk production and growth of kids of local, multipurpose goats grazing on dry season natural Sahelian rangeland in Mali. Animal Science, 71: 165-173.

Sanogo S, Shaker MM, Nantoumé H, Salem AFZ. 2012. Milk yield and composition of crossbred Sahelianx Anglo-Nubian goats in the semi-intensive system in Mali during the preweaning period. Tropical Animal Health and Production, 45: 305310. DOI: http://dx.doi.org/10.1007/ s11250-014-0555-z

Snyman M. 2010. Factors affecting preweaning kid mortality in South African Angora goats. South African Journal of Animal Science, 40 (1).

Ukanwoko AI, Ibeawuchi J Okeigbo A. 2012. Effects of sex, breed and season on birth weight of kids and effect of season on kid mortality in South Eastern Nigeria. $J$. Anim. Prod. Adv., 2: 469-472.

Tshibangu MI, Kampemba MF, Kashala KC, Kiatoko MH, Hornick JL. 2014. Composition chimique et indice de palatabilité des feuilles de Adenodolichos rhomboideus Leucaena leucocephala et Stylosanthes guianensis chez la chèvre locale à Lubumbashi. Int. J. Biol. Chem. Sci., 8(3): 937-945, DOI : http://dx.doi.org/10.4314/ijbcs.v8i3.10

Zahraddeen D. 2009b. Evaluation of some factors influencing growth performance of local goats in Nigeria. African Journal of Food, Agriculture, Nutrition and Development, 8(4): 464-479.

Zahraddeen D, Butswat I, Mbap S. 2009a. A Note on Factor influencing Milk Yield of local Goats Under Semi-Intensive System in Sudan Savannah Ecological Zone of Ngeria. Livestock Research for Rural Development, 21(3). 